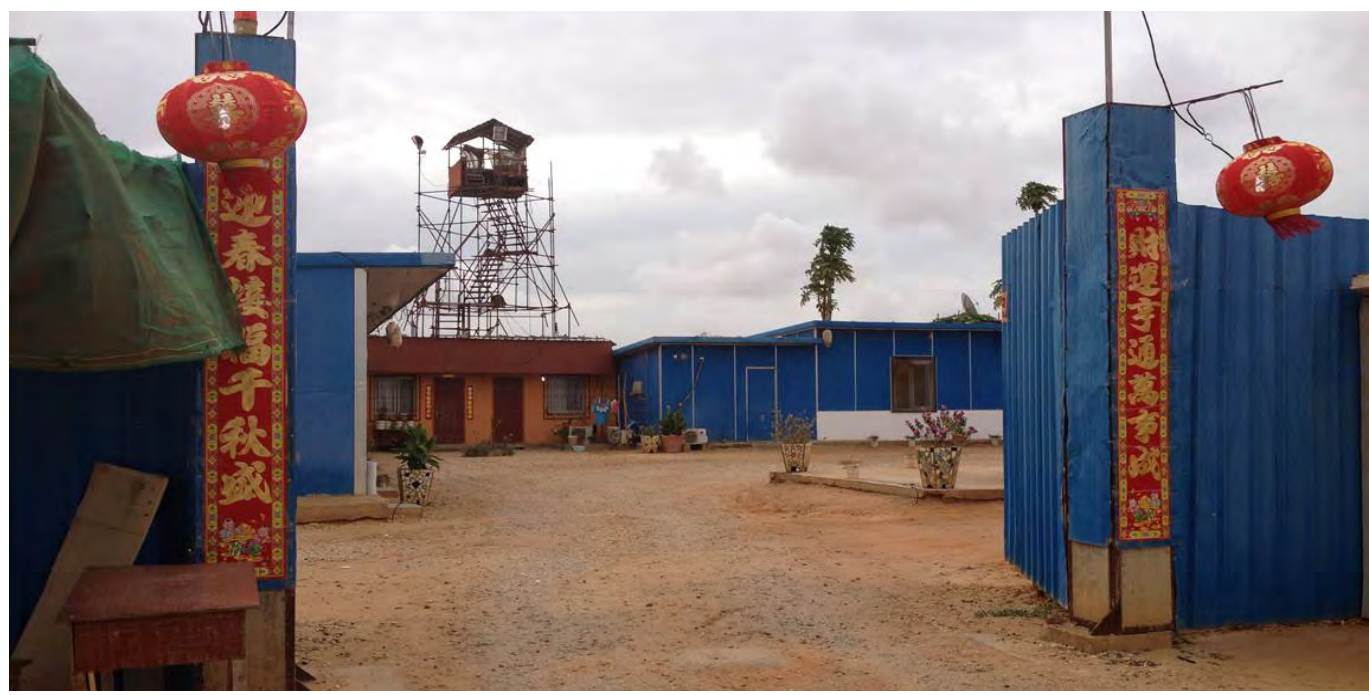

\section{Doing Time, Making Money at a Chinese State Firm in Angola}

Cheryl Mei-ting SCHMITZ

Popular accounts of the expansion of Chinese capital in Africa have presented it as a rapid and exciting process of furious movement and violent transformation. By contrast, fieldwork conducted among employees of a Chinese stateowned construction firm in Luanda, Angola, in 2013-14 reveals repetitive rhythms of monotony and boredom. This essay explores how Chinese migrant workers in Angola experienced their time abroad as work without life, despite spending much of their time every day engaged in non-productive activities. Justifying their deferment of 'life' with dreams of what their money would eventually buy in China, and attempting to contrast their own 'hard work' against an image of idle Africans or Americans, the Chinese men the author met in Angola were ultimately pretty bored.
Entrance to Chinese compound, Luanda 2014. PC: Cheryl Mei-ting Schmitz. $\mathrm{n}$ late 2013, I arrived in Luanda, the capital of Angola, for a year of research on the recent boom of Chinese investment and labour migration in the region. An acquaintance introduced me to $\mathrm{Li}$ Jun (pseudonym), a 27-year-old manager at a Chinese stateowned construction firm that I will call 'The Angola Company'. His company, like many others, had come to Angola in the early 2000s under the auspices of the massive National Reconstruction Program established at the end of the 27-year-long Angolan civil war. The Angolan Government contracted Chinese companies to build infrastructure, paying for the projects with loans from Chinese financial institutions backed by Angolan oil. The arrangement was criticised by suspicious observers as a form of 'new imperialism', while 
Chinese and Angolan state actors praised it as a pragmatic and mutually advantageous partnership.

As an ethnographer, I was less interested in casting moral judgement about 'China in Africa' than in understanding how China-Africa relations were experienced through everyday life. At one of our first meetings, I relayed this vague anthropological goal to manager Li. I wondered whether I might conduct participant observation at his company's base, which consisted of dormitories and offices built on the corner of a construction site. His response surprised me. 'I understand. You want to know not only how Chinese people work here, but also how they live. But,' he cautioned, 'you should know one thing: Chinese people do not live in Angola; we only work.'

In what follows, I explore why Chinese managers and workers at The Angola Company considered their existence in Angola to be a kind of non-life. They insisted on the allencompassing nature of their work, although much of their time was occupied by nonproductive activity, or what some would classify as 'leisure' (Veblen 2007: 33). Their days were indeed hard, but not because they were busily immersed in toil. Ironically, it was a repetitive, enforced idleness that they endured in the service of expanding China's global reach.

\section{Temporary Machines}

Li Jun's characterisation of the Chinese migrant experience in Angola was in part derived from the way many companies from China structured time and space for their workers. Like many Chinese companies in Angola at the time of my fieldwork, his employer followed a seven-day workweek, with days 'off' only on major Chinese holidays, like National Day or the Lunar New Year. Chinese employees repeated the same routine of waking up, going to a certain location for work, and returning to their dormitory, day after day, for the entire length of their contract, which was typically one and a half or two years. They lived and worked on the company premises, and most staff were not permitted to leave the compounds after $6 \mathrm{pm}$. Had they been given permission to leave company grounds more often, employees would still not have been able to do much, since their salaries were paid into bank accounts in China, accessible only on their return. Many claimed to like this arrangement, saying that it allowed them to save more money and kept them physically safe.

Workers were thus available to work extremely long hours. In the past, construction sites were sometimes kept operational late into the evenings to meet tight deadlines. However, by the time I moved into a dormitory of The Angola Company, work appeared to be both all-consuming and strictly limited. Lunch breaks and midday naptime were religiously maintained, as was dinner time, meaning everyone had to be back at the dormitories before the canteen opened at $6 \mathrm{pm}$. The evenings were 'free' for employees to take walks in circles around the compound or play cards and drink beer in their dormitories. However, if one of the directors suddenly announced that one of us had been 'invited' to a drinking banquet with his business associates, it would have been unthinkable to refuse. One's time, therefore, even outside official working hours, was not completely one's own, and it could never be spent outside the social or physical space of the company.

In their recent ethnographies of Chinese labour in Zambia and Ethiopia, respectively, Ching Kwan Lee (2017) and Miriam Driessen (2019) quote Chinese migrants making comparisons to prison, citing the physical discomfort of their spare living conditions, restrictions on spatial mobility, lack of entertainment, social isolation, and the machine-like repetitiveness of their work. Chinese workers with whom I spoke also highlighted the inhuman quality of their working conditions, though usually through sarcastic comments rather than righteous cries 
of injustice. 'Chinese people here are like robots [机器人], ' Li Jun would often joke. 'Every day at the same time we get out of bed, go to work, get off work, and go home, and at night we recharge our batteries!' A technician in the engineering department, Han Han, told me, chuckling: 'We are like machines, or the walking dead [ $P$ 体走 肉]! It was only when he returned home, Han said, when he finally saw the arid landscape surrounding his hometown in northwestern China from the airplane window, that he felt he 'came alive' again (我就活了!).

\section{Counting the Days}

Anthropologist Xiang Biao has written about contemporary overseas migration from China as 'a temporal rather than a spatial project' (Xiang 2014: 192). Migrants, both those who actually find opportunities abroad and 'wouldbe' migrants who live in a state of anticipation, are driven by what they call a 'last bus mentality'-the fear that they may be missing out on the wealth accumulation occasioned by China's rapid development in the post-reform era (Xiang 2014: 191). For those desperate not to be left behind, a transformation in socioeconomic conditions would be brought about not by travelling to a new location and beginning life afresh, but rather by taking a detour through work abroad to skip ahead in the race for enrichment. Importantly, as Xiang emphasises, although migrants move across borders, their aspirations remain fixedly oriented towards China-the place to which they eventually return and where they resume full participation in life. From such a perspective, concerns such as 'integration' into a 'host society' become utterly irrelevant. What matters is only the future-a future firmly rooted in China.

If Chinese migrants considered their work in Angola merely a detour from life in China, what was the content of their work? When I began visiting The Angola Company regularly,
I assumed everyday life would be filled with bustling activity, that these men on the front lines of Chinese globalisation would be sweating under the hot Angolan sun, diligently building wealth along lines of South-South solidarity.

What I witnessed instead surprised me. I arrived in Angola at a specific moment, a decade after the beginning of postwar reconstruction, when, at least for The Angola Company, payments had been delayed on several government construction projects, and therefore work had slowed. Moreover, there were complaints that the construction market had become 'saturated' with Chinese competitors and was no longer the gold mine it had appeared to be when the company first arrived in 2005. While company headquarters attempted, slowly, to change their business development strategy and expand into other sectors, office staff and technicians languished, dawdling around the various compounds to which they were confined, their heads filled not with grand schemes of global expansion but with modest dreams about how, once back in China, they would spend the salary they still steadily earned. In this context, they had to find ways to pass the time.

An accountant, Ma Hui (pseudonym), had already been working in Angola for more than five years when I met him, but he spoke very limited Portuguese. Since I frequently helped with translation at the company, he asked whether I would be willing to teach him what I knew of the language. This request, however, was not primarily motivated by a desire to communicate with Portuguese-speakers. Ma explained: 'It's just that life is really so boring here. I just want to feel like I've done something over the next year, before I go back [to China].' I agreed to help and, for the next few weeks, we met every day after lunch to read dialogues out of a Portuguese textbook. Ma Hui's coworkers expressed genuine admiration at his commitment, reporting to me that he had stopped playing cards with them and instead spent his evenings reviewing vocabulary. 
Less than a month later, however, Ma suddenly announced that he wanted to take a break from studying. 'I think I want to wait until after Christmas to continue,' he said. Then Christmas passed, and he said he wanted to wait until after Lunar New Year. After that, he revealed to me that he had become fully absorbed in a video game introduced to him by Wang Tao, a colleague in the logistics department. The game, played online with multiple participants all over the world, involved building up a fortified compound and amassing gold by attacking and plundering other players' settlements.

'Are these all your soldiers?' I asked, staring at some squirming purple figures on the screen.

'Yeah!' he said proudly. 'And this is all my money. Look how big Wang's fortress is! Mine's still pretty small, but I can build it up over time. I just want to feel like I've done something over the next few months, before I go back [to China].'

Through his attempts to pass time-first, by studying Portuguese, then by playing a game online-Ma Hui searched for a sense of accomplishment. Why would he need to intentionally seek this out, and through activities that I would assume fell outside the scope of his responsibilities as an accountant? The apparent emptiness of his workdaysin terms of both the availability of time for leisure activities and the experience of having achieved nothing-intrigued me. How could Chinese employees at The Angola Company be both working all the time and apparently not working at all?

Indeed, Ma Hui's experience was not unique. Many of the several hundred Chinese men employed by the company spent their days in Angola engaged in activities that had nothing to do with company business: reading news on their phones or iPads, chatting and smoking cigarettes, tending to potted plants, watching movies, or making calls to friends and relatives in China. These were activities designed to fill time, or make it pass, as they counted down the days until they returned to
China and life as understood in any meaningful sense. Employees' time at work, which was all their time as long as they were in Angola, did not have to be economically productive because, as long as they were abroad, they were 'working'. What was apparently 'hard' about their situation was not the work itself (see also Driessen 2019: 161), but their social isolation, the monotonous schedule-so repetitive that everyone, including me, forgot what day of the week it was-and, ultimately, the boredom.

\section{Globalisation through Boredom}

Boredom, according to Baudelaire, involves 'being caught in a dull state of permanent anticipation'; for Benjamin, it signifies 'the atrophy of experience' (both cited in Masquelier 2013: 481). This uniquely modern affect is thus intimately tied to temporality. As Edmund Leach (1968: 135) long ago proposed, time flow is ideally perceived through the alternation of qualitatively different experiences, such as mundane daily routines punctuated by festivals, which 'create time by creating intervals in social life'. By contrast, boredom can be understood as 'a state of being where the experience of time dissolves or stops being of relevance' (Musharbash 2007: 307). More specifically, Leach argued that the experience of time involves recognition of two distinct processes: first, people notice repetitions-of water dripping from a roof, for instance, or the chime of a clock marking an hour's passagethat are in some sense the same thing, but with a difference; second, people recognise change over the course of a life cycle, such as the universal process of birth, ageing, and death (Leach 1968: 132). The combination of endless repetition alongside progressive change is what allows one to feel movement through time (Masquelier 2013: 482). By contrast, amid the boredom of, for example, unemployed youth in Niger or residents of an Aboriginal settlement 
in Australia, what is experienced are not 'new moments' but 'an endless repetition of the same' (Musharbash 2007: 313).

Notably, many recent ethnographic accounts of boredom have focused on the experiences of the unemployed (see, for instance, Jeffrey 2010). Specifically, jobless young African men have emerged as a prominent population among whom to undertake studies of boredom. Whether in Ethiopia (Mains 2007) or Senegal (Ralph 2008), urban male youth who, lacking waged work, spend much of their time preparing and drinking tea, seem to exist in a perpetual state of enforced leisure. They 'kill time' (Ralph 2008: 15) not in anticipation of some expected social event, but because they find themselves caught in a permanent state of 'waithood', held back from participation in waged labour and therefore from the achievement of an ideal masculine adulthood (Masquelier 2013: 475; Dhillon and Yousef 2009). Another favoured setting for the anthropology of boredom has been among impoverished communities excluded from state services or made to wait indefinitely for them. In administrative offices from Argentina (Auyero 2012) to Latvia (Ozolina-Fitzgerald 2016), waiting is imposed on populations as a technique of governance, meant to induce passivity and subjection (see also Grill 2018).

By contrast, the bored men I encountered at The Angola Company were neither unemployed nor neglected by social welfare institutions. Instead, the enforced leisure they experienced was due to a state of total employment, work without life, in which their every daily need was met by the company. One might be tempted to read this situation as a legacy of Chinese socialism, through which individuals' time would have been completely 'captured' (Verdery 1996) by the Maoist state to eliminate possibilities for subversive activity. In the twenty-first century, however, managers at this state-owned construction firm were more interested in competing against private companies on the Angolan market than they were in political ideology. The Party secretary of The Angola Company regularly urged younger managers to become entrepreneurs rather than serve the Communist Party, and many employees openly mocked the idea of Chinese-African brotherhood, insisting they had come to Angola for one reason alone: to make money.

\section{Making Work}

Earning up to ten times what equivalent positions would have garnered in China, employees of The Angola Company could, over the course of a few years, amass enough savings to buy property, get married, acquire a private vehicle, or book an international vacation-all necessary ingredients for social survival in twenty-first-century China (see also Driessen 2019: 161). Moneymaking was not only central to these men's purpose of working in Angola; it was also a core part of the way they defined work itself. After I had been living and working on company grounds for about a month, shadowing employees as they went about their daily routines, and accompanying members of the trade department to their offices every day to assist with translation, I decided I needed a change of routine. I wanted a regular period of uninterrupted time to write up and analyse my field notes, to read, and perhaps to visit people I knew outside The Angola Company, whether for fieldwork purposes or simply 'for fun'. Some of my 'coworkers' at the company said they had noticed that I seemed tired. 'We made the mistake of treating you like one of us,' one of the young managers said sympathetically.

Despite their 'work without life' often appearing, to me, more like 'work without work', Chinese managers claimed the ability to work hard, and incessantly, was a particularly Chinese virtue (for just one example of the vast academic discussion of this question, see Harrell 1985). Although I considered reading and writing to be kinds of 'work', whenever I did take time away from the company, my coworkers would usually tell me, mockingly, to 'have a good rest!'. They sometimes made 
comments that I 'needed to rest' because I was American, not Chinese. In response, I asked whether all employees would not benefit from having at least one day of rest per week. Was it not possible, I asked, that this could even have the effect of making employees work more productively the rest of the time?

'Actually, this idea of resting one day per week,' one of the men explained to me, 'it originally came from the West. If you think about it, before the Republican Period [191149], who ever heard of the concept of rest?'

'That's right,' his coworker chimed in. 'Some elderly men and women in China, they've probably never had a day of rest in their lives! They may have taken time off at Lunar New Year, but celebrating a festival is different from resting. Human beings always need an adjustment period.' He addressed me directly: 'If you grew accustomed to working every day you wouldn't feel the need to rest either.'

The first speaker added: 'Angola is a very good example of that. In the past, local people always had to rest on Sundays. They said they had to go to church to pray. Later, Chinese people told them, if you go to church is God going to give you a salary? Then they saw that Chinese people running businesses here stayed open on Sundays, and they also gradually began to open their shops on Sundays, instead of attending church.'

'That's right,' his friend agreed. 'They realised that if they did business on Sundays, they could make more money!'

Moneymaking requires exploitation-this is an old lesson from Marx, which the wageearning men at The Angola Company knew well. Instead of a flurry of productive activity, however, Chinese businesses maintained their competitiveness through boredoman all-encompassing kind of restriction that included enforced leisure. This system allowed for the total availability of labour, from both managers and workers, which could, in theory, be deployed to complete projects quickly as a highly disciplined and docile workforce. In practice, it was experienced as passive waiting, a deferment of life, justified through claims about the particularly Chinese capacity for hard work. Boredom, in this case, was not imposed on company men as a form of discipline. Rather, what enabled employees' exploitation and therefore moneymaking was the fact that their aspirations were always oriented elsewhere, so that progressive time, and therefore 'life', could be suspended, while work, which was actually an unenjoyable kind of leisure, could take its place for a year, two years, or ten. Ironically, Chinese expansion in Africa, so frequently depicted by journalists as rapid, exciting, and even violent, was experienced by those on its front lines as dull, repetitive, and monotonous-experiences similar to those anthropologists have observed among unemployed African youth.

At least this was how it looked from my perspective. From the perspective of the company employees, whether they were producing something or not, as long as they were earning wages, they were working, and as long as I was not, whatever I was doing could not count as 'work'. They, more than I, were willing to admit that they engaged in 'selfexploitation' (Han 2015; see also Graeber 2018), and not for the vain ambition of intellectual achievement, but to make money-perhaps a much humbler goal. 
This text is taken from Made in China Journal: Volume 5, Issue 3, 2020, edited by Ivan Franceschini and Nicholas Loubere, published 2021 by ANU Press, The Australian National University, Canberra, Australia.

doi.org/10.22459/MIC.05.03.2020.06 